\title{
The spread of visceral leishmaniasis in Brazil: the first canine cases described in Ji-Paraná, Rondônia, Brazil
}

\author{
A disseminação da leishmaniose visceral no Brasil: os primeiros casos caninos \\ descritos em Ji-Paraná, Rondônia, Brasil
}

\begin{abstract}
Aliny Pontes Almeida1* (D); Antonio Marques Pereira Júniorr,3; Paula Frassinetti Medeiros de Paulo²; Adriano Mendes Marchandeau Pinto'; Bruna Bastos Boroviec'; Geysa Almeida Viana1;

Moisés Thiago de Souza Freitas ${ }^{4}$; Renata Benício Neves Fuverki'; Ricardo de Godoi Mattos Ferreira ${ }^{3,5}$, Jansen Fernandes Medeiros 2,3

\author{
${ }^{1}$ Curso de Medicina Veterinária, Centro Universitário São Lucas, Ji-Paraná, RO, Brasil \\ ${ }^{2}$ Laboratório de Entomologia, Fundação Oswaldo Cruz - Fiocruz, Porto Velho, RO, Brasil \\ ${ }_{3}^{3}$ Instituto Nacional Epidemiologia da Amazônia Ocidental - INCT-EpiAmO, Porto Velho, RO, Brasil \\ ${ }^{4}$ Núcleo de Saúde, Centro Universitário do Vale do Ipojuca - UNIFAVIP, Caruaru, PE, Brasil \\ ${ }^{5}$ Laboratório de Epidemiologia Genética, Fundação Oswaldo Cruz - Fiocruz, Porto Velho, RO, Brasil
}

How to cite: Almeida AP, Pereira Júnior AM, de Paulo PFM, Pinto AMM, Boroviec BB, Viana GA, et al. The spread of visceral leishmaniasis in Brazil: the first canine cases described in Ji-Paraná, Rondônia, Brazil. Braz J Vet Parasitol 2021; 30(4): e011021. https://doi.org/10.1590/S1984-29612021085

\begin{abstract}
Leishmaniases are zoonotic diseases caused by protozoa of the genus Leishmania. The disease has two clinical manifestations described in humans: visceral (VL) and cutaneous (CL) leishmaniasis. In Brazil, there has been an expansion of human VL. The participation of the dog as a reservoir of Leishmania infantum, the agent of $\mathrm{VL}$, is important for the epidemiology of the disease since canine cases generally precede human cases. The present study aimed to evaluate the occurrence of Leishmania spp. infection in dogs in the municipality of Ji-Paraná by PCR assays using blood samples. Leishmania DNA was detected in two of the 105 studied dogs. The PCR products were sequenced and confirmed that the two samples (1.90\%) correspond to L. infantum. The dogs had allochthonous history. Therefore, the positive results found here should serve as a warning to public health agencies. This is because Ji-Paraná is the third municipality to register cases of canine leishmaniasis (CanL) in Rondônia state. Thus, reinforcing the importance of expanding studies on the epidemiology and surveillance of $\mathrm{VL}$ in the region.
\end{abstract}

Keywords: Leishmania infantum, dogs, Rondônia.

\begin{abstract}
Resumo
As leishmanioses são doenças causadas por protozoários do gênero Leishmania. A doença apresenta duas manifestações clínicas: leishmaniose visceral (LV) e cutânea (LC). No Brasil, a LV está em expansão. A participação do cão como reservatório é importante para a epidemiologia da doença, pois os casos caninos geralmente precedem os humanos. O presente estudo avaliou a ocorrência de LV em cães (LVC) do município de Ji-Paraná por meio de ensaios de PCR, utilizando-se amostras de sangue. O DNA de Leishmania foi detectado em dois dos 105 cães estudados. Os produtos da PCR foram sequenciados e confirmaram que duas amostras (1,90\%) eram Leishmania infantum. Os cães tinham histórico alóctone. Os resultados positivos encontrados servem de alerta aos órgãos públicos de saúde. Isso porque Ji-Paraná é o terceiro município a registrar casos de LVC no estado de Rondônia. Dessa forma, reforça-se a importância da ampliação dos estudos sobre a epidemiologia e vigilância da LV na região.
\end{abstract}

Palavras-chave: Leishmania infantum, cães, Rondônia.

Received June 12, 2021. Accepted October 1, 2021.

*Corresponding author: Aliny Pontes Almeida. E-mail: apa_pontes@hotmail.com 
Visceral leishmaniasis (VL) is a zoonotic disease caused by the protozoan Leishmania infantum in Latin America. The sand fly Lutzomyia longipalpis is the main vector for L. infantum (Torres-Guerrero et al., 2017). In Brazil, there has been an expansion of human VL. The disease was reported in 21 states and the Federal District, with potential of autochthonous cases from Amazonas, Amapá, Rondônia, Paraná, and Santa Catarina (Reis et al., 2017). Some factors that contribute to the expansion of this disease include the adaptation of the vector to diverse conditions, including urban areas and participation of domestic dogs (Canis familiaris) as the most important reservoir of VL (Reis et al., 2017). The participation of the dog as a reservoir is important for the epidemiology of the disease since canine cases generally precede human cases (Dantas-Torres, 2007).

Rondônia State is endemic for cutaneous leishmaniasis (CL), with an average of 1,000 cases per year. To date, no human cases of VL have been recorded in Rondônia. However, L. longipalpis and canine cases have been recorded in recent years. Aguiar et al. (2010) performed the first study on canine leishmaniasis (CanL) in Rondônia. They found that dogs had a seroprevalence of $27.9 \%$ for Leishmania spp. Silva et al. (2018) recently reported the first autochthonous case of CanL in Cacoal municipality. In addition, Ziemniczak et al. (2021) recently reported a case of CanL in Rolim de Moura municipality. These findings highlight the importance of assessing the potential for future human cases, given that $\mathrm{VL}$ is on the rise in Brazil. This paper presents the first cases of visceral leishmaniasis in dogs in Ji-Paraná County, Rondônia, in the western Amazonian region of Brazil.

The present study was conducted in the municipality of Ji-Paraná, Rondônia (Figure 1). The sample included 105 dogs from urban and rural areas that arrived at the Veterinary Hospital of Centro Universitário Luterano de Ji-Paraná CEULJI/ULBRA between 2016 and 2018. This study was approved by the Animal Ethics Committee (CEUACEULJI/ULBRA; no. 2016/163).

A)

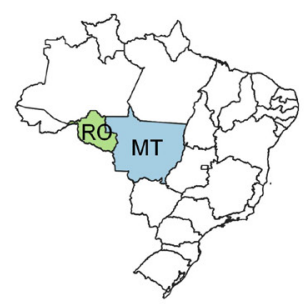

C)
B)

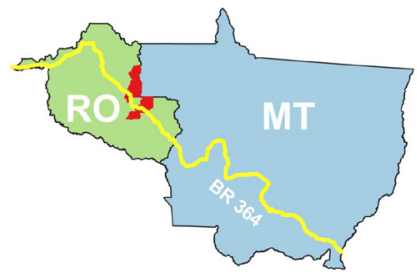

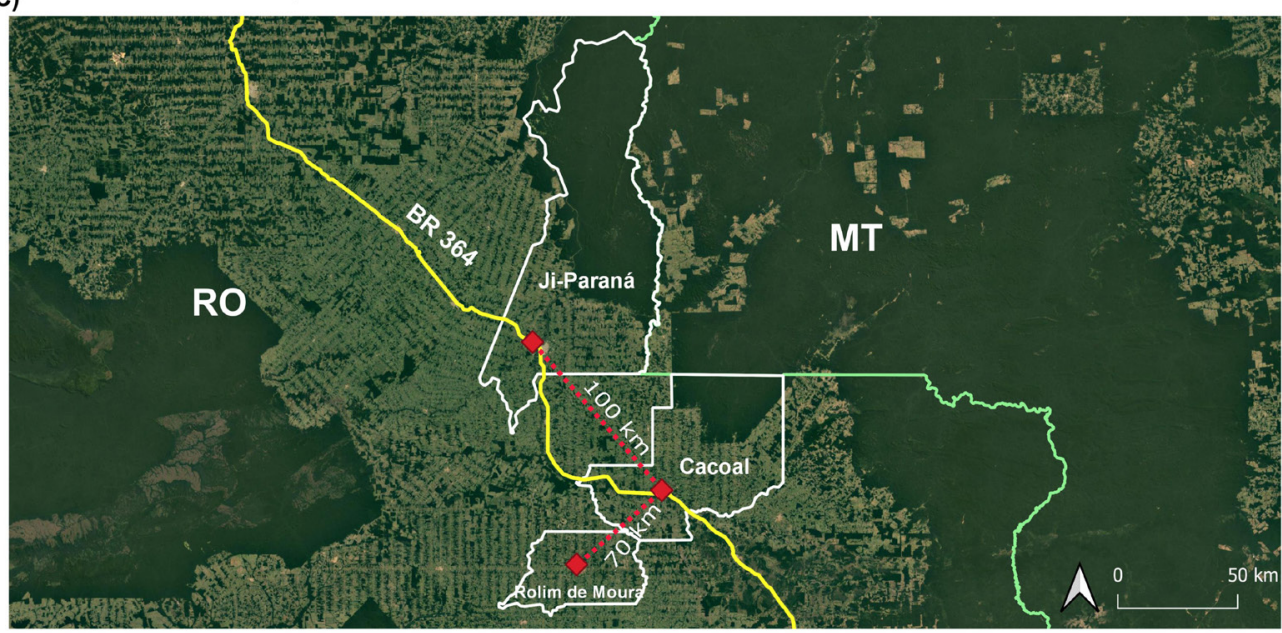

Figure 1. (A) Brazil map with the political territory of Rondônia and the Mato Grosso States; (B) Highway road 364 and municipalities of Rondônia State with cases of canine visceral leishmaniasis; (C) Distance between the municipalities of Rondônia State with confirmed cases of canine visceral leishmaniasis.

Initially, data such as age, sex, locality, and travel history of the dogs were obtained. The dogs were evaluated for the presence of the clinical signs of CanL, including skin lesions, nasal ulcers, progressive weight loss, hepatomegaly lymph node or spleen enlargement, onychogryphosis, and cachexia. Then, $1.5 \mathrm{~mL}$ of peripheral blood from each animal was collected and stored $\left(-20^{\circ} \mathrm{C}\right)$ in phosphate-buffered saline (PBS) until use. 
DNA extraction was performed using the Illustra Blood Mini Spin Kit (GE Healthcare Life Sciences, Buckinghamshire, United Kingdom). PCR assays targeted kDNA, according to Oliveira et al. (2005), using the primers 5-GGG(G/T)AGGGGCGTTCT(G/C)CGAA-3 and 5-(G/C)(G/C)(G/C)(A/T)CTAT(A/T)TTACACCAACCCC-3 (120 bp). Positive samples were subjected to PCR targeting the $h s p 70$ region using the primers 5-GGACGAGATCGAGCGCATGGT- 3 and 5-TCCTTCGACGCCTCCTGGTTG-3 (240 bp) (Graça et al., 2012). PCR products were checked on a 2\% agarose gel and purified using the ExoSAP-ITM PCR Product Cleanup Reagent (ThermoFisher Scientific, California, USA). Purified PCR products were sequenced at the Fiocruz sequencing facility (RTP01E). The $h s p 70$ gene was sequenced in duplicate for each sample, and the sequences obtained were assembled and analyzed using the Staden package (Staden, 1996) based on Phred values of 20 or above (Ewing \& Green, 1998). The consensus sequences were submitted to a BLASTn search (NIH, 2021).

The consensus nucleotide sequence for each sample was aligned using MUSCLE (Edgar, 2004), incorporated into the MEGA v. 6.0 software (Tamura et al., 2013), and compared to Leishmania braziliensis (KY249630.1), Leishmania amazonensis (EU599090.1), and Leishmania infantum (MF137828.1). This alignment was used to construct a phylogenetic tree using the neighbor-joining method, as implemented by the MEGA v. 6.0, software (Tamura et al., 2013). The consistency of the branches was assessed using 1.000 bootstrap replicates. The sequences generated in this study were deposited in the GenBank database under the accession numbers MZ057078 and MZ057079.

A total of 105 dogs were evaluated being 26 pups (14 females, 12 males) and 79 adults (46 females, 33 males), 94 were born in Ji-Paraná, while 11 were from other localities out of Rondônia state; 95 dogs were from urban areas and 10 were from rural areas. Of the 105 evaluated, 30 dogs were diagnosed as with clinical signs, 72 without clinical signs, and 3 as missing data.

PCR was performed for all samples, and 12 samples (7 with clinical signs, 5 without clinical signs) were successfully amplified for kDNA molecular primers, and when these positive samples were applied to the $h s p 70$ target, two samples (both with clinical signs) were successfully amplified (Table 1). These positive samples for the $h s p 70$ gene were sequenced, and a $233 \mathrm{bp}$ fragment was obtained. These sequences were compared to other sequences available in GenBank using the BLASTn tool and then identified as L. infantum (query cover $=99 \%-100 \%$, identity $=98 \%-99 \%$, GenBank accession MF137828.1).

Table 1. Profile and diagnostic of dogs evaluated in Ji Paraná municipality between 2016-2018. o+: female, つ̋: male

\begin{tabular}{|c|c|c|c|c|c|c|c|c|c|}
\hline & & \multicolumn{2}{|c|}{ Dog origin } & \multicolumn{2}{|c|}{ Area } & \multicolumn{4}{|c|}{ PCR targets } \\
\hline \multicolumn{2}{|c|}{ Dogs evaluated } & \multirow{2}{*}{ Ji-Paraná } & \multirow{2}{*}{ Out RO } & \multirow{2}{*}{ Urban } & \multirow{2}{*}{ Rural } & \multicolumn{2}{|c|}{ kDNA } & \multicolumn{2}{|c|}{ hsp70 } \\
\hline & & & & & & - & + & - & + \\
\hline With clinical signs & 30 (+15ð15) & 25 & 5 & 29 & 1 & 23 & 7 & 28 & 2 \\
\hline Without clinical signs & $72(+43 ð 29)$ & 68 & 4 & 64 & 7 & 67 & 5 & 72 & 0 \\
\hline Missing Data & $3(+2 \precsim 1)$ & 1 & 2 & 2 & 2 & 3 & 0 & 3 & 0 \\
\hline Total & $105(6045)$ & 94 & 11 & 95 & 10 & 93 & 12 & 103 & 2 \\
\hline
\end{tabular}

૧: female, §̊: male

To ratify the molecular identity of Leishmania spp., a phylogenetic tree was generated using three species. Phylogenetic analysis indicated the presence of an isolated clade with a support value of $93 \%$ formed by individuals of the L. infantum species, while L. braziliensis and L. amazonensis were separated, creating another distinct clade (Figure 2). This result confirmed the identity of the sequences obtained in this study. This is the first record of $L$. infantum species identified in the Ji-Paraná observed in allochthonous dogs.

In the first case, a 4-year-old Great Dane crossbreed went through veterinary care in April 2018 after experiencing progressive weight loss and development of dermatological lesions. During anamnesis, the owner of the dog reported that the animal was acquired in Paraguay, had lived in the cities of Cacoal and Presidente Medici, also located in Rondônia, and had been living in Ji-Paraná for the past two years. Dermatological examination revealed ulcerous lesions in the nasal plane (Figure 3A), hyperkeratosis of the palmar and plantar cushions (Figure 3B), and alopecia and hypotrichosis of the ear associated with moderate hyperkeratosis. Moderate lymphadenomegaly and 


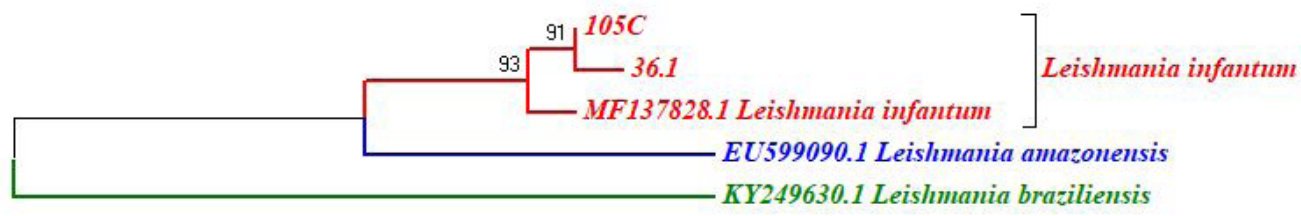

0.01

Figure 2. Comparison of the evolutionary relationship between Leishmania infantum, Leishmania amazonensis, and Leishmania braziliensis species from $h s p 70$ gene sequences using the Neighbor-Joining method.

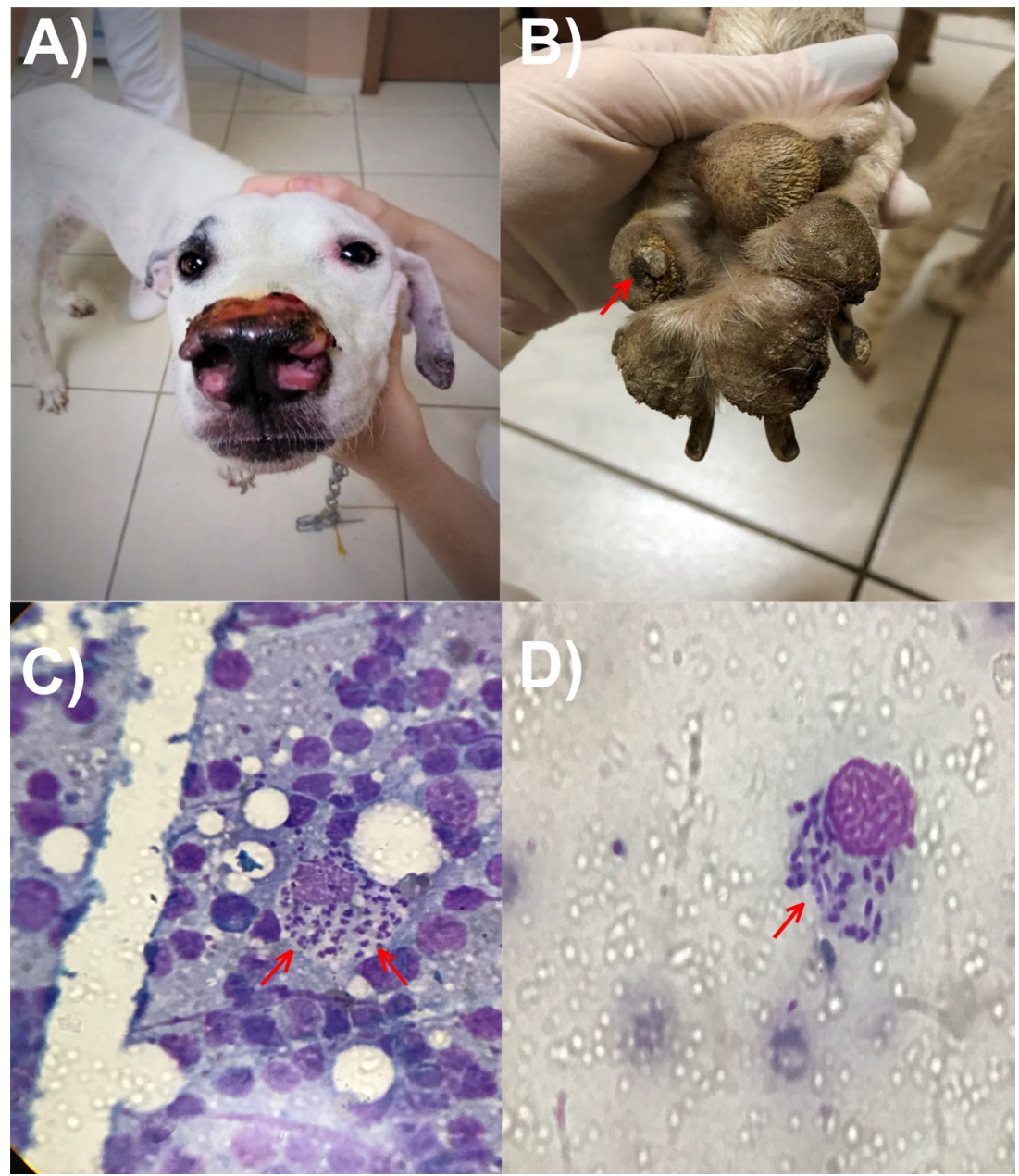

Figure 3. (A) Female Canine Great Dane Crossbreed: Poor nutritional status and ulcerative lesions in the nasal plane and ear tip hyperkeratosis; (B) Intense plantar cushion hyperkeratosis and onychogryphosis; (C) Amastigote forms present in bone marrow (40x); (D) Amastigote forms in macrophages from lymph node aspirate (100x).

splenomegaly were also observed. In addition, bone marrow, lymph node, and skin lesion aspirates were subjected to microscopic analysis to identify amastigote forms (Elmahallawy et al., 2014). Samples revealed amastigote forms compatible with Leishmania spp. both in the cytoplasm of macrophages and outside of these cells (Figure 3C-D). In this dog, a serum sample was submitted to the Dual Path Platform (DPP) assay, and the serological test was positive for CanL.

The second case was an eleven-year-old female Labrador retriever, seen for routine examinations at a veterinary hospital (UniSL) in August 2017. During anamnesis, the owner of the dog reported that the animal had been diagnosed and treated for leishmaniasis and that the diagnosis was confirmed by serological testing conducted in 
Mossoró, State of Rio Grande do Norte. Physical examination showed malnourishment, hepatomegaly, splenomegaly, lymphadenomegaly, and ear lesions characterized by areas of alopecia, hyperkeratosis, and ulcerations. In this dog, samples of whole blood and lymph node aspirate collected obtained a positive PCR result in both samples.

This paper reports, for the first time, cases of L. infantum in dogs in the Ji-Paraná, a region that is considered as non-endemic for CanL. In addition, it confirms that Ji Paraná is the third municipality in the state of Rondônia with cases of CanL and alerts the fact that the disease could be present in other municipalities. Recently, autochthonous cases of CanL were reported in the central region of the state in the municipalities of Cacoal and Rolim de Moura (Silva et al., 2018; Ziemniczak et al., 2021). Previously, antibodies against Leishmania spp. were found in dogs in the municipality of Monte Negro (Aguiar et al., 2010). The main clinical manifestations identified in infected dogs are commonly observed in dogs with CanL: dermatological lesions, onychogryphosis, lymphadenomegaly, splenomegaly, and hepatomegaly (Ribeiro et al., 2018). In our study, samples that were kDNA positive but did not amplify the $h s p 70$ gene region could be infected with other trypanosomatid species, since this gene is specific for Leishmania species.

We found that 11/105 of the evaluated dogs had an epidemiological history of not being from Rondônia, including the two positive cases. The occurrence of visceral leishmaniasis in non-endemic areas may be related to migration and environmental changes, or the difficulty of effective control against potential vectors (Salomón et al., 2015). Particularly in Rondônia, it was observed that there has been a colonization process related to the inauguration of the BR-364 highway, the agricultural and livestock activities that resulted in deforestation and exchange of ombrophilous forests for clean fields (Brown et al., 2005; Fearnside, 2016). These factors together could contribute to the facilitation of new transmission cycles. Other possibility for presence of CanL could be vertical or venereal routs (Oliveira et al., 2015). Interestingly, all the municipalities with reported cases are located in the southern portion of the state; Rolim de Moura and Ji-Paraná are $70 \mathrm{~km}$ and $100 \mathrm{~km}$ away from Cacoal, respectively (Figure 1C). In addition, the municipalities are near the BR 364 route, with a constant migratory flow into the region that connects Rondônia to Mato Grosso, a neighboring state endemic for VL and that had registered an expansion of VL cases in its territory (Mestre \& Fontes, 2007). Both Cacoal and Ji-Paraná are border cities with Mato Grosso, which could be an entry route for silent cases of human or infected dogs in Rondônia, hence the control of migrating domestic animals could be an important surveillance in the region considering that there are positive autochthonous cases in localities near Ji-Paraná.

Another possibility is the presence of $L$. Iongipalpis, which has already been recorded in Rondônia, but in low abundance (Gil et al., 2003; Teles et al., 2013). In these non-endemic areas, these cases could be related to alternative vectors. Recently, it was shown that some species can successfully act as vectors for the transmission of $L$. infantum, such as Lutzomyia cruzi (dos Santos et al., 1998), Migonemyia migonei (Guimarães et al., 2016), and Pintomyia fischeri (Galvis-Ovallos et al., 2017). Rondônia has a diverse fauna of potential vectors. However, all species are associated with cutaneous leishmaniasis (Gil et al., 2003; Silva et al., 2021). Therefore, more studies are needed to monitor the presence of $L$. longipalpis or the presence of a secondary CanL vector.

Our study evidenced the presence of CanL cases in an area previously considered non-endemic. Further studies are necessary to evaluate the epidemiological risk of CanL in Rondônia. Some questions need to be clarified for the region, such as the distribution of $L$. longipalpis, which is still uncertain. Furthermore, more studies on vector surveillance associated with canine surveillance in municipalities with CanL and in regions bordering Mato Grosso, where there is a large migratory flow are needed.

\section{Acknowledgements}

We thank the Foundation for Research Support of Rondônia (FAPERO) for financial support.

\section{References}

Aguiar DM, Oliveira TMFS, Cavalcante GT, Labruna MB, Camargo LMA, Machado RZ, et al. Seroprevalence of anti-Leishmania spp. antibodies in rural dogs from the city of Monte Negro, State of Rondônia, Brazil. Rev Bras Parasito/ Vet 2010; 19(1): 71-72. http://dx.doi.org/10.1590/S1984-29612010000100015. PMid:20385065.

Brown JC, Koeppe M, Coles B, Price KP. Soybean production and conversion of tropical forest in the Brazilian Amazon: the case of Vilhena, Rondônia. Ambio 2005; 34(6): 462-469. http://dx.doi.org/10.1579/0044-7447-34.6.462. PMid:16201218. 
Dantas-Torres F. The role of dogs as reservoirs of Leishmania parasites, with emphasis on Leishmania (Leishmania) infantum and Leishmania (Viannia) braziliensis. Vet Parasitol 2007; 149(3-4): 139-146. http://dx.doi.org/10.1016/j.vetpar.2007.07.007. PMid:17703890.

dos Santos SO, Arias J, Ribeiro AA, de Paiva Hoffmann M, de Freitas RA, Malacco MA. Incrimination of Lutzomyia cruzi as a vector of American visceral leishmaniasis. Med Vet Entomol 1998; 12(3): 315-317. http://dx.doi.org/10.1046/j.1365-2915.1998.00104.x. PMid:9737605.

Edgar RC. MUSCLE: multiple sequence alignment with high accuracy and high throughput. Nucleic Acids Res 2004; 32(5): 17921797. http://dx.doi.org/10.1093/nar/gkh340. PMid:15034147.

Elmahallawy EK, Sampedro Martinez A, Rodriguez-Granger J, Hoyos-Mallecot Y, Agil A, Navarro Mari JM, et al. Diagnosis of leishmaniasis. J Infect Dev Ctries 2014; 8(8): 961-972. http://dx.doi.org/10.3855/jidc.4310. PMid:25116660.

Ewing B, Green P. Base-calling of automated sequencer traces using Phred. II. Error Probabilities. Genome Res 1998; 8(3): 186-194. http://dx.doi.org/10.1101/gr.8.3.186. PMid:9521922.

Fearnside PM. Environmental and social impacts of hydroelectric dams in Brazilian Amazonia: implications for the aluminum industry. World Dev 2016; 77: 48-65. http://dx.doi.org/10.1016/j.worlddev.2015.08.015.

Galvis-Ovallos F, da Silva MD, Bispo GBS, de Oliveira AG, Gonçalves JR No, Malafronte RS, et al. Canine visceral leishmaniasis in the metropolitan area of São Paulo: Pintomyia fischeri as potential vector of Leishmania infantum. Parasite 2017; 24: 2. http:// dx.doi.org/10.1051/parasite/2017002. PMid:28134092.

Gil LHS, Basano SA, Souza AA, Silva MGS, Barata IR, Ishikawa EA, et al. Recent observations on the sand fly (Diptera: Psychodidae) fauna of the State of Rondônia, Western Amazônia, Brazil: the importance of Psychodopygus davisi as a vector of zoonotic cutaneous leishmaniasis. Mem Inst Oswaldo Cruz 2003; 98(6): 751-755. http://dx.doi.org/10.1590/S0074-02762003000600007. PMid:14595450.

Graça GC, Volpini AC, Romero GAS, Oliveira Neto MP, Hueb M, Porrozzi R, et al. Development and validation of PCR-based assays for diagnosis of American cutaneous leishmaniasis and identification of the parasite species. Mem Inst Oswaldo Cruz 2012; 107(5): 664-674. http://dx.doi.org/10.1590/S0074-02762012000500014. PMid:22850958.

Guimarães VCFV, Pruzinova K, Sadlova J, Volfova V, Myskova J, Brandão SP Fo, et al. Lutzomyia migonei is a permissive vector competent for Leishmania infantum. Parasit Vectors 2016; 9: 159. http://dx.doi.org/10.1186/s13071-016-1444-2.

Mestre GLC, Fontes CJF. A expansão da epidemia da leishmaniose visceral no Estado de Mato Grosso, 1998-2005. Rev Soc Bras Med Trop 2007; 40(1): 42-48. http://dx.doi.org/10.1590/S0037-86822007000100008. PMid:17486252.

National Center for Biotechnology Information - NIH. [online]. USA: NIH; 2021 [cited 2021 June 10]. Available from: http://blast. ncbi.nlm.nih.gov/Blast.cgi

Oliveira JG, Novais FO, de Oliveira Cl, da Cruz AC Jr, Campos LF, da Rocha AV, et al. Polymerase chain reaction (PCR) is highly sensitive for diagnosis of mucosal leishmaniasis. Acta Trop 2005; 94(1): 55-59. http://dx.doi.org/10.1016/j.actatropica.2004.12.003. PMid:15777720.

Oliveira VVG, Alves LC, Silva VA Jr. Transmission routes of visceral leishmaniasis in mammals. Cienc Rural 2015; 45(9): $1622-1628$. http://dx.doi.org/10.1590/0103-8478cr20141368.

Reis LL, Balieiro AAS, Fonseca FR, Gonçalves MJF. Changes in the epidemiology of visceral leishmaniasis in Brazil from 2001 to 2014. Rev Soc Bras Med Trop 2017; 50(5): 638-645. http://dx.doi.org/10.1590/0037-8682-0243-2017. PMid:29160510.

Ribeiro RR, Michalick MSM, da Silva ME, Dos Santos CCP, Frézard FJG, da Silva SM. Canine Leishmaniasis: an overview of the current status and strategies for control. BioMed Res Int 2018; 2018: 3296893. http://dx.doi.org/10.1155/2018/3296893. PMid:29789784.

Salomón OD, Feliciangeli MD, Quintana MG, Afonso MMS, Rangel EF. Lutzomyia longipalpis urbanisation and control. Mem Inst Oswaldo Cruz 2015; 110(7): 831-846. http://dx.doi.org/10.1590/0074-02760150207. PMid:26517497.

Silva ANR, Pereira AM Jr, de Paulo PFM, da Silva MS, Castro TS, Costa GDS, et al. Detection of Leishmania species (Kinetoplastida, Trypanosomatidae) in phlebotomine sand flies (Diptera, Psychodidae) from Porto Velho, Northern Brazil. Acta Trop 2021; 213: 105757. http://dx.doi.org/10.1016/j.actatropica.2020.105757. PMid:33189711.

Silva CJ, Mattos CB, Felipin KP, Silva HPJ, Cantanhêde LM, Porrozzi R, et al. First autochthonous case of canine visceral leishmaniasis in Rondônia, Brazil, a region with no history of visceral leishmaniasis. Rev Soc Bras Med Trop 2018; 51(5): 712-715. http://dx.doi. org/10.1590/0037-8682-0143-2017. PMid:30304285

Staden R. The staden sequence analysis package. Mol Biotechnol 1996; 5(3): 233-241. http://dx.doi.org/10.1007/BF02900361. PMid:8837029.

Tamura K, Stecher G, Peterson D, Filipski A, Kumar S. MEGA6: molecular evolutionary genetics analysis version 6.0. Mol Biol Evol 2013; 30(12): 2725-2729. http://dx.doi.org/10.1093/molbev/mst197. PMid:24132122. 
Teles CB, Basano SA, Zagonel-Oliveira M, Campos J, Oliveira AF, Freitas RA, et al. Epidemiological aspects of American cutaneous leishmaniasis and phlebotomine sandfly population, in the municipality of Monte Negro, State of Rondônia, Brazil. Rev Soc Bras Med Trop 2013; 46(1): 60-66. http://dx.doi.org/10.1590/0037-868216062013. PMid:23563827.

Torres-Guerrero E, Quintanilla-Cedillo MR, Ruiz-Esmenjaud J, Arenas R. Leishmaniasis: a review. F1000Res 2017; 6: 750. http:// dx.doi.org/10.12688/f1000research.11120.1. PMid:28649370.

Ziemniczak HM, Silva GHL, Maia MO, Ferreira E, Saturnino KC, Santos-Doni TR. Canine visceral leishmaniasis in Rondônia, Brazil: a report of an autochthonous case. Acta Vet Bras 2021; 15(1): 15-18. http://dx.doi.org/10.21708/avb.2021.15.1.9422. 